\title{
Development, Tourism and Commodification of Cultures in Vanuatu
}

\author{
Marc Tabani
}

\section{Introduction}

Anthropology has long considered that the drastic social and cultural changes that affected the island societies of the Western Pacific now belong to the past. It was currently held that the definitive historical and societal break followed upon the global process of colonisation and Christianisation, and was achieved with a second great wave of western influences during and after World War II. These earlier massive, destructive and violent cultural impacts were not necessarily fatal, but nonetheless they had irrevocable consequences. However, a host of new exacerbating factors have contributed over the long term to the destabilisation of a precarious societal balance and to the weakening of cultural and religious syncretisms that Melanesian islanders succeeded in elaborating and maintaining in earlier colonial times, while periodically reshaping them up until the early period following independence.

Such cumulative ruptures seem at least to have deeply altered traditional capacities to change progressively (Sahlins 1992, 1999) when they have not also westernised many attempts at coping with indigenization of modernity' or 'develop-man' processes (see Robbins 2005; Babadzan 2009). 
Former nationalist leaders envisioned the road to independence in Vanuatu as a process of 'modernization without Westernization' (Babadzan 1988: 222); however, successive governments to this day have not been able, in that country, to offer anything more, to many of their fellow citizens, than the prospect of resigning themselves to the idea of a creeping westernisation without the benefits of modernisation.

For two decades, neoliberal reforms along with a general political fragmentation in state governance (Hassall 2007; Morgan 2004) have been accelerating factors in the rapid social and cultural changes occurring in Vanuatu. Divlopmen is a notion that has been widely popularised by Bislama (Vanuatu's Creole language). Frequently understood only in a very abstract manner by most inhabitants of rural areas, nonetheless it is perceived, more or less, by many of them as an obstacle to the continuation of their kastom. The most tangible aspects of this powerful dynamic of economic and social transformation of societies of the so-called 'outer islands' are multiple: an increasing rural exodus, the intensive growth of foreign investment and land-grabbing, an ubiquitous tourism whose impact is seen as ambiguous, the generalised monetisation of rural communities and the emergence in them of new forms of social inequalities, the construction of a middle class of rural origins, as well as the rise of individualism and advanced forms of consumerism (comparatively with Papua New Guinea (PNG), see Errington and Gewertz 1999).

Very similar to the proletarianisation of peasantries elsewhere in the Third World, this phenomenon has not previously been experienced in Vanuatu, at least not on the same scale (Rodman 1987). One of its features is the spread of real poverty from its urban settings (BryantTokalau 1995) to the more populous rural zones. The growing social dependence on manufactured imported food also increases the prospect that hunger will pose a serious threat for greater numbers of people in the case of natural disaster. ${ }^{1}$ Eighty per cent of Vanuatu households now possess a mobile phone after its introduction in 2007, while 100 per cent of them are constantly increasing their consumption of imported rice. It is not at all surprising that, in order to guarantee national cohesion and state stability, after saving lives, the next priorities declared under the state

1 In considering the question of self-sufficiency as to food production in Vanuatu, a quantitative study has recently shown that among six village communities in six densely populated islands, imported processed food bought in retail shops constitutes close to 50 per cent of all food consumed by the average household (Lebot et al. 2014). 
of emergency in the wake of cyclone Pam in March 2015 were urgent distributions of rice and the rapid repair of the Global System for Mobile Communications (GSM) network in the outer islands.

Vanuatu is typically characterised as a predominantly rural country, inhabited by a majority of peasants who are more or less dependent on subsistence farming. However, except for inefficient local bureaucracies or international organisations and NGOs in league with them, who could seriously claim that 75 per cent of the country's population is still rural (Vanuatu Millennium Development Goals Report 2010)? Migrationshort- or long-term, circular or permanent, sometimes seasonal—between Port Vila and 'the islands' developed as a highly complex process in terms of spatial cultural continuities (Lindstrom 2011). Thousands of unqualified rural workers who are recruited in all regions of the country are being employed overseas on short-term (Recognised Seasonal Employers Scheme in New Zealand and Australia) or long-term contracts (employment on Taiwanese fishing boats). The strict delimitation between what could be defined in Vanuatu as 'urban', 'peri-urban' and 'rural' is obviously blurred on Efate (around Port Vila), as it is on the southeast coast of Santo (around Luganville). More and more people near Lenakel (Tanna), Lakatoro (Malekula) or Longana (Ambae) are adopting urban lifestyles and livelihoods. Local observers agree that the total urban population of Vanuatu can, on occasions, be doubled. ${ }^{2}$ To be urbanised in Vanuatu today means first and foremost to have temporarily or permanently left behind the semi-cash economy inherited from the colonial era, and to remain in a zone of direct state intervention (see Rio 2011).

Vanuatu is listed among the least developed countries and receives regular funding for poverty reduction programs although, officially, poverty is seldom mentioned in the country's internal debates. Locally the word 'poverty' is sometimes considered as inappropriate in describing its socioeconomic realities. In an 'untouched island paradise', ranked highest according to alternative wellness indicators - the 'happiest country in the world'-people cannot really be considered to be poor, rather they should be seen as rich on account of their culture, environment and diversity.

2 During his visit to Vanuatu in 2013, Senator Bob Carr, then Australian Minister for Foreign Affairs, mentioned in his official speeches that Port Vila numbered 60,000 inhabitants ('Australia's Minister for Foreign Affairs visits Port Vila', Vanuatu Times, 15 February 2013). If one considers that in Vanuatu the usual process of 'circular migration' toward urban areas is overall becoming permanent and cumulative, then it would be quite plausible to claim that the real demographic divide between the 'urban' and 'rural' population is much closer to a ratio of 40 to 60 than to the official figure of 25 to 75 . 
Wealthy members of the ruling class would add that redistribution mechanisms inherent to kastom ekonomi $i^{3}$ are sufficient to mitigate an unbalanced distribution of wealth. Despite the protests of Ephraïm Kalsakau, the national leader of the United Trade Unions and Vanuatu Labour Party, in Vanuatu the 'justice for the poor' program of the World Bank and AusAID has been renamed 'justice for everyone' (jastis blong evriwan) (JBE meeting, discussion notes, Port Vila, 4 February 2010). What neoliberal entrepreneurs now share with former Melanesian socialists is this ideological motivation to deny the capitalist process of class formation; while 'God never went on strike' (Lini quoted in Howard 1983: 198), kastom is also praised for making no divisions between rich and poor and it can even serve as pretext 'to "lock" many ... people into pre-capitalist forms of production, and as population pressure and the desire for cash increases, these people form a 'reserve army' of cheap labor for the bourgeoisie' (ibid.: 202). ${ }^{4}$

During my fieldwork research in Vanuatu, ${ }^{5}$ I have always devoted a great deal of attention to the observation of the cultural impacts of ongoing socioeconomic development in different rural zones of the archipelago, and especially on the island of Tanna where I have spent most of my time. To assess whether the numerous and rapid changes that have occurred in the meantime are as profound, extensive and violent as the earlier significant historical disruptions is not an easy matter, but we might presume that they are at least as irrevocable in terms of their cultural consequences. But such powerful transformations have never before been so strongly influenced by the development of tourism as the country's main industry. Shortly after independence, tourism had already become the primary source of national income through directly or indirectly related activities, but its

3 The year of the kastom ekonomi, officially celebrated by the Republic of Vanuatu in 2007 and whose mission was extended to 2010, seems like a final resurgence of the idea of Melanesian socialism that saw kastom as a 'force for development' (see below). In the presentation of this program by the present minister of lands and former director of the Vanuatu Cultural Centre, Ralph Regenvanu, it is instructive to note that underdevelopment or poverty, which are never named, are attributed not to the incompatibility between two systems, but to the decline of customary chiefs who are no longer able to assume their role as mediators between the needs of the market and a domestic mode of production. In order to remedy this situation he proposes institutionalising neotribal chiefs, suggesting they should be called 'State Chiefs', so as not to confuse them with 'customary clan chiefs', their role somewhat resembling the function of the Assessors under colonial rule (Geismar and Regenvanu 2011: 43).

4 This still alarmist forecast in the 1980s has become a reality today.

5 From 1993 till 2009, I led a dozen fieldwork trips in Vanuatu, lasting from two to nine months each. From 2010 till 2014, I lived permanently in Port Vila and spent a large part of my time on Tanna Island for the management of several anthropological and cultural projects. 
steady and continuous growth continues to be quite spectacular. Less than 10,000 people visited Vanuatu in 1987, visitors numbered 40,000 in $1995,100,000$ in 2002 and 300,000 in 2012. Tourist arrival figures are considered as 'amazing' and 'phenomenal' by the Vanuatu Hotels and Resorts Association (The Independent of Vanuatu no. 468, 16 February 2013). The record number of tourists is also attracting increasing foreign investment frequently motivated by the prospect of quick profits or easy land-grabbing. ${ }^{6}$ Since its beginnings, tourism development has never followed any 'socialist way' in Vanuatu (see Douglas 1996: 245), it was always 'largely dominated by international intermediaries and expatriate owner-managers, mostly Australians and New Zealanders resident in Vanuatu' (Cheer 2015).

In Vanuatu, policymakers unanimously consider tourism to be the leading economic sector through which the country should strengthen its development. No matter the extent of damage caused by the monster tropical cyclone Pam in 2015 or warnings about the necessity for Vanuatu to diversify its economy, among Vanuatu's economic and political elites an unshakeable belief in the benefits of tourism seems to have become a matter of faith. Following an historical overview describing the conversion of Vanuatu to a cult of development, which for the tourism industry sometimes seems reminiscent of a new form of cargoist expectations, ${ }^{7}$ in this chapter, I will highlight some aspects of the cultural price to pay for the extension to rural zones of the problematic economic sector of 'ethnic tourism'.

In this brief exposition I shall discuss two sets of data documenting local aspects of the process of the commodification of cultures, through which a commoditised kastom is turned into a mere tourist attraction. First, I shall provide a short historical survey of the ideological background

6 If land-grabbing in Vanuatu has been oriented toward tourist development for two decades (see De Burlo 1989), the pressures on coastlines is now driving islands like Efate and Santo toward a systematic process of land alienation.

7 It would take too long to look further into the question of the prophetic, indeed messianic, posture regularly adopted by numerous Vanuatan political figures, but I refer the reader to the large file on the speculative dealings of the former prime minister Moana Carcasse concerning the construction of a new airport on the island of Efate, which would bring in 'millions' of Asian tourists to Vanuatu, dealings that are directly linked to the fall of his government in March 2013. Of the same order are the murky plans supported by other public authorities to establish a new age 'artists' colony' on Tanna, driven by a New York hip hop prince known by the ghostly alias of DJ Spooky. The project had to be abandoned on Tanna but seems to be going ahead on Efate (Basic project info: Vanuatu Pacifica Foundation website. Online: www.the-vpf.org/ (accessed 12 September 2016)). 
of the kastom and development rhetoric in Vanuatu. This issue will highlight some of the outcomes of mass tourism on Tanna, especially the increasing monetisation of rural economic systems and its influence on indigenous representations of traditional culture and social relationships. I shall add some brief comments about other problematic aspects of the commodification of kastom, when it is related to the organisation of huge traditional ceremonies. In this perspective I shall argue that mass tourism, as a factor of drastic change, does not act to strengthen kastomwhatever the alterations of cultural forms, values and practices that are precisely involved in this process. I shall leave analysis of issues such as the individual or national economic advantages of the development of tourism in Vanuatu to the field of tourism studies, which already boasts an impressive literature on this and related questions. The value of anthropology for analysing also the losses of values (see Paini and Gnecchi-Ruscone, Introduction, this volume) will lead me to make some concluding comments on the disturbing issue of the 'prostitution of culture' as a metaphor of some of the worst aspects of Melanesian or Pacific modernities.

\section{Development and kastom}

'Development', asserted a founding father of the Republic of Vanuatu on the eve of independence, is merely 'another word for change' (Lini 1980: 30). Traditional island cultures, in the view of a first generation of young, educated Melanesian nationalists, should no longer be seen as 'the most resistant to change'. If kastom (tradition) is continuously being transformed it must serve as 'a force for development' (ibid.), rather than presenting an obstacle. Together with Christian principles, Melanesian values were emphasised by the newly independent state to embody its imagined continuity with precolonial forms of sovereignty and development, and to promote the renewal of an idealised indigenous 'communal way' that had been undermined through 70 years of colonial rule and the imposition of a capitalist economy. Socialist policies were first presented by ni-Vanuatu nationalists as being more suitable for Melanesia in order to maintain a balance between national economic imperatives (globally driven modern changes) and the social and cultural requirements of kastom (locally inspired indigenous changes). 
Socialism is not a 'dirty word' insisted another founding father, Barack Sope (1974: 53), but rather a modern notion that simply translates indigenous ideas about what he deemed to be the main characteristics of a timeless 'Melanesian village life': 'no hierarchical barriers and egalitarian principles [that] are evident in many aspects of social structures' that had been in existence for hundreds of years before the establishment of the New Hebrides Condominium (ibid.: 54). However, the influence of the 'myth of Melanesian Socialism' (Howard 1983) in framing national development plans in Vanuatu was of very short duration, and even more limited. In fact, since the beginning of Vanuatu's independence, the control over the formal economy by state institutions mostly inherited from the colonial system has been the 'least socialistic' among Pacific Island states (ibid.: 193; see also Premdas 1987; Miles 1998; Tabani 2002). The political elites of Vanuatu have never confirmed any real desire on their part to embrace socialist development. An international context, marked by the collapse of the Soviet empire, facilitated the 'Melanesian way' abandoning its initial 'socialist touch'. Since the official neoliberal turn taken by Vanuatu at the end of the 1980s, the encouragement of foreign investment and the strengthening of national capital held by an urban middle class have remained a constant theme in the country's economic guidelines and one that has continually been reaffirmed since then, most recently with the ratification in 2012 of Vanuatu's World Trade Organization (WTO) membership.

In comparison with socialism, the national rhetoric promoting kastom has become a real success story in Vanuatu. Even when not all groups praise the value of kastom (Taylor 2010: 282), it is still a major strategic notion in the national political arena, a main ideological prerequisite for maintaining the spirit of 'unity within diversity', one always brandished by state authorities in their quest for popular legitimacy and officially presented as the basis of national cohesion. Kastom not only became an affaire d'état (Miles 1998: 71; see also e.g. Babadzan 1988; Tabani 2002; Holtz 2010) but also a focal point for socioeconomic development. But neither before nor after the bankruptcy of the state in the 1990s, the severe reform program begun in 1997 (known as the Comprehensive Reform Program) or the Millennium Development Fund in 2004 has kastom succeeded in becoming clearly a 'force for development'. Instead, foreign powers started to become even more suspicious about some of the 
political uses and abuses of the concept that, in the post-Lini era, was sometimes suspected of concealing the growth of a massive system of corruption.

But more and more criticism is now targeting its economic dimension. Open access for international companies to local resources and to the national market has, in the views of foreign investors and development agencies, now become a main criterion for the acceptability of kastom, where kastom must be seen to be compatible with their interests. More than ever, in the present global context, the non-market-friendly aspects of kastom are assessed as 'obstacles to development' (Babadzan 2006). ${ }^{8}$ Surviving premodern modes of production and neotraditional authorities serving as intermediaries with a modern colonial system are an inherited part of the older variant of capitalism that most Pacific Islands states perpetuated in their early phase of independence. Today this twofold system is under lethal threat from 'a more advanced form of capitalist penetration that no longer required chiefs or tradition (except to entice tourists)' (Howard 1983: 180).

\section{Early history of tourism in Tanna}

In the 1980s, tourism in the outer islands of Vanuatu was strictly restricted, mainly for reasons of cultural and social preservation but also, more prosaically, because of a lack of basic infrastructure. Outside the island of Efate and its capital Port Vila, only tourists who had their day trips organised by tour operators, yachtspeople and cruise ship operators were allowed to travel in isolated rural zones. This prohibition also applied to some other areas, for similar reasons. Before 1994, when the Vanuatu Cultural Centre (VKS Vanuatu Kaljoral Senta) lifted a moratorium on cultural research, foreign academic fieldworkers were also banned from rural zones. The measure was intended to preserve the stability of the structures of the newborn state of Vanuatu after various disturbances had occurred during the independence period, especially on the islands of Santo and Tanna, at present two of the main tourist destinations outside

8 During a political meeting in Tanna in June 2008, the late Edouard Natapei, then minister, campaigned on the theme of the necessity of giving up kastom when it appeared as an obstacle to divlopmen - a proposal that, for numerous participants, amounted shockingly to an appeal to dispense with Christian values, because in the collective imagination, just as in the constitution, custom and Christianity go together. 
Efate. Today, the nation state's stability no longer seems to rely on such direct political control over foreign activities in the country. The main goal now is to develop the country, to encourage people and communities to engage in business and to earn income.

Predictions about the advent of tourism as a major industry in Vanuatu can be dated to the late 1960s (Douglas 1996: 239-41). The speculative projects of the 1970s that aimed to build residential homes for thousands of US Vietnam War veterans on Santo can also be related to cargo tourism expectations of this kind. ${ }^{9}$ These economic predictions were not realised until quite recently, with developments that began less than 20 years ago and that are just starting to reveal all of their societal impacts. At the beginning of the 1990s, after more than a decade of independence, just one hotel, limited in capacity, was established on Santo, together with some other tourist bungalows on Tanna known as the Tanna Beach Resort $^{10}$ and formerly operated by an Australian expatriate, Bob Paul. Both establishments were in the upper medium price range, and tended to specialise in all-inclusive group tours. Bob Paul arrived on Tanna in 1946. He was in the vanguard of the island's tourism business when he launched Company Tours in 1960, founded the first private domestic airline company and initiated the construction on Tanna of the first airstrip (Dunn 1997). Regardless of how underdeveloped the island was in pre-independence days and how 'primitive' the living conditions of its people were deemed to be by the colonial society in Port Vila, its suitability for tourism was assured by the presence of Mt Yasur, one of the most accessible volcanoes in the world, together with other beautiful natural attractions.

According to Joël Bonnemaison, tourism was causing problems on Tanna and 'by 1970, incidents involving local villagers had become increasingly frequent. Bob Paul set up a profit-sharing scheme whereby he would give the people of Ipekel, a village that is the headquarters of his John Frum

9 In 1967, Jimmy Stevens, leader of the Santo-based Nagriamel indigenous movement, had contacted Eugene Peacock, an American land speculator wishing to invest in the New Hebrides. Peacock, whose commercial activities were based in Hawai $i$, had acquired vast areas of land, on Santo in particular. His plan was to subdivide these properties into small plots in order to sell them on to American Vietnam veterans (see Beasant 1984: 45).

10 As a result of a conflict between local landowners and the resort owners, the lodge (renamed Tanna Lodge) was mostly burned to the ground in July 2015. 
opponents, ${ }^{11}$ two Australian dollars per tourist, an appreciable amount of money at the time' (1994: 307). As a consequence of that conflict, the John Frum people closed the volcano to tourists for nine months in 1977-1978, causing several violent incidents. ${ }^{12}$ To explain their decision, John Frum leaders from Ipekel sent a letter to the French District Agent that ended with the words 'no tourist, no money, no problem'. Mweles, a leader of the millenarian John Frum movement in Sulphur Bay (southeast Tanna), added that 'he was weary of quarrels caused by money', and concluded with the motto 'kastom ino laekem mani' (custom does not like money) (ibid.). 'Such a philosophy was not always easy to understand. Disenchanted, the trader Bob Paul stated: My troubles began on the day I decided to share my profits and involve the John Frum in my business' (ibid.).

Similar incidents were reported by Lindstrom in the same period. Christian and kastom groups quarrelled about whether or not to accept money from Paul's tourists to allow them to participate in the great nakwiari ceremonies (sometimes mislabelled toka dances) (Lindstrom 1982: 326); other groups entered into conflicts about the control of kastom when some of them wanted to perform their dances in a secularised context in Port Vila (ibid.: 237). What is remarkable about these early conflicts is that even if they originated from the tension between kastom and money, namely exploiting kastom to make money, the amounts were too limited to have any serious large-scale socioeconomic impact. From the 1970s until today the number of tourists has increased a thousandfold (exceeding 15,000 a year in Tanna) and the charge for a visit to the volcano has increased from \$US2.50 to $\$$ US50. Two questions quickly arose from this first period of tourism development: is kastom saleable as a spectacle and, more broadly, who has the right to use kastom for non-customary purposes not legitimated by kastom, whether political, commercial or scientific? Exploitation through

11 John Frum is the name of a famous millenarian politico-religious movement (and of its main cultic spirit) born at the end of the 1930s in Tanna. Western fascination with John Frum has contributed to making it one of Melanesia's most famous cargo cults. The cargo cult label applied to the John Frum myth became an essential selling point for Tanna in the tourism market (see Lindstrom 1993).

12 The conflicts that arise out of the exploitation of the volcano Yasur for tourism have been constant on Tanna since the 1970s. Here too, without going into detail, a thesis alone would not suffice, let me say simply that the main part of the profits (probably more than 90 per cent according to a report that appeared in the 'Mt Yasur Volcano Fees', Vanuatu Daily Post, 2 December 2014) has been pocketed by a private firm basing its legitimacy on 'customary land rights' (these same land rights being constantly contested by other groups). This profit, which could be in the vicinity of US $\$ 1$ million per year, is only very marginally redistributed among the island's population. The maintenance of the road for a month yields a kompani of 10 men chosen in turn by a village the sum of $\$ 20$ per person per month. 
wage labour, humiliating wage-earning conditions, modern political uses of kastom, an understanding of the western world surrounding them as a huge accumulation of commodities: these are realities that have been experienced by people from Tanna for several decades. Nevertheless, the awareness of the possibility of also transforming kastom into a commodity was new. More surprising, at first glance, is the fact that Christian groups who were the first to reject their kastom have in certain local cases also been the initiators of its commodification.

Tanna Beach Resort was not one boasting luxury accommodation. But since it was expensive, it was dedicated to upmarket tourism. This elite tourism had contributed to creating problems on Tanna, but their real cause was still mainly political. Bob Paul was believed by the John Frum people and the kastom groups to be a strong supporter of the Vanuaaku Pati (VP), the nationalist party that led the country to independence. 'His store, house and tourist bungalows in Lenakel were located in the midst of Christian, predominantly VP, territory, therefore he was considered as the ally of VP partisans' (Bonnemaison 1994: 307). He was seen by these groups as perpetuating the pre-war dictatorial rule of the Presbyterian mission and the British colonial authorities, known in the history of the island as the 'Tanna Law' period. In contrast, Bob Paul's business did not create major social problems, nor was it a source of growing social inequalities. In that period (1970-1990), the number of tourists was limited (never more than a few hundred in a year), though a majority of children in the islands would still never have seen white foreigners face-to-face. ${ }^{13}$

Nevertheless, the lack of tourist infrastructure in this early period did not necessarily discourage overseas visitors. In fact it may have led to forms of tourism that were also a burden on local populations. The commodification of culture has been fostered by market forces, but these might often conflict with customary prescriptions about taking care of, and sharing with, foreign visitors. I remember guide books in the 1990s giving tips on how to sleep for free in ni-Vanuatu villages—in other

13 The island children of today, unlike those of 20 years ago, now ask for sweets or pens when they meet foreign visitors whom they used to call Elobabae. All those tourists and all those sweets, but the outsiders would often restrict their communication with island residents to elementary forms of politeness, that is, 'hello' immediately followed with 'bye-bye'. 
words saving money by staying with people who have none. John Peck and Robert Gregory have highlighted that this was already the case in the 1970s on Tanna:

Tourist grade housing is unavailable on the outer islands, but there are usually some sort of accommodations that can be used such as Government 'guesthouses' (usually an empty thatched roof hut with some sort of stove and beds) or occasionally travellers can stay in Mission facilities, if arrangements are made in advance. These more primitive facilities are beginning to attract small groups of campers and people who really want to 'rough it'. The hazards of the trip are sufficiently exciting so that everyone usually enjoys an authentic 'experience'. One problem with this sort of tourist activity, however, is that it places a difficult and often unrecognized burden on the local population. When a camper arrives in one of the outer islands, the local people have no option but to accept and take care of him or her, partially because custom requires them to share with a stranger, partially because there is nowhere to get rid of the stranger (2005: 274).

The quest for authenticity, which tourism has largely contributed to promoting from the very beginning of its local development, was not without consequence as regards the objectification of the Tannese cultural heritage. The ideological dimension of kastom and the state encouragement of ethnic tourism have meant that the islanders have become self-reflexive in relation to their own lifeways. Lukluk vilej laef (to observe villagers' everyday life), for example, is a formula used in former times to explain and justify rural tours and visits by colonial delegates, police, missionaries and anthropologists in exercising their control over the population. Today it is used to rationalise the perceived interest of tourists in villagers' traditional life. The tourists do not really know what to expect from such cultural experiences, but the villagers have been taught, even trained, how best to nourish their fantasies. The tourists' desire to experience kastom everyday life directly means that islanders have themselves incorporated exotic aspects valued by foreigners into their own lives. For the last 15 years, this has led to a multiplication of 'kastom villages' on Tanna as elsewhere in the country.

These villages are ordinary living places, neither more nor less traditionalist than other places in Vanuatu. The only difference resides in the fact that they are intentionally marketed as 'traditional'. This means that it is the inhabitants themselves who have to select and emphasise the tangible aspects of their culture that they think will be of interest to tourists. One 
of the main options for tourists in Tanna is to choose between the different degrees of traditionality on offer: between a 'full kastom' cultural show and display enacted by performers in strictly traditional dress (the men wearing penis sheaths and the women appearing bare-breasted) or attired in neotraditional dress (lava-lava) for the men and coconut bras for the women) (Robinson and Connell 2008; see also Connell 2007). They no longer simply live their culture, they now perform it for the purpose of 'culturalist safaris'. ${ }^{14}$ This does not mean that their performed culture is no longer authentic, but it is obviously dependent on a global market:

The traditional/neo-traditional 'culture' that tourists consume is both real and manufactured in the sense that people nourish and protect traditions partly because these can be sold to visitors hungry for the sensation of difference. Islanders dance for reasons more important than money; dance still functions as it always has to bring together people from two regions. But tourism, too, promotes and motivates cultural performance and islanders have for touristic reasons become careful to husband and manage cultural resources whether these are dance, religious ceremony, art style, or a cuisine (Lindstrom 2015: 186).

\section{The fast-growing mass tourism on Tanna}

The harbinger of mass tourism in Vanuatu was the opening of a number of 'cabins' at the Port Resolution Nipikinamu Yacht Club in Tanna in 1994. In Port Resolution, adventurous tourists can experience a tropical paradise lying well off the beaten track. A tiny peninsula fringed with beautiful white sand beaches, a sheltered lagoon, an easily accessible active volcano and a significant historical and cultural heritage site where Captain Cook himself is the first western visitor now remembered. With none of the usual modern facilities-no electricity, no stores, no running water, no internet connections and, before 2008, no mobile phonesit is a fabulous world's end location. At the beginning of the 1990s, an income-earning project financially supported by foreign aid was launched to promote tourism in Port Resolution but in a way that respected its unique and fragile environment.

14 I borrowed this formula from Alain Babadzan, personal communication, 11 November 2012. 
Local people, with the help of David Sharland, a British volunteer business development officer working for the Vanuatu Government, started with the building of a Robinson Crusoe-style yacht club. After its official opening in August 1992, the second phase of the project, the construction of local-style cabins where overseas short-term visitors can take part in village life as paying guests, was completed in December 1994. The whole community was involved in decision-making for the project. This was a key component in establishing and managing it. A project committee ran the day-to-day business, while the chiefs only stepped in if there were any serious problems. Each employee from the village (kitchen staff, house girls, guides, gardeners, etc.) received a small personal remuneration and the rest of the benefits were used for community needs. Local food and handicrafts were made available for sale. In this way the income earned from foreign visitors remained within the local community. Twenty years later, this project of small-scale or basic tourism, which had the hallmarks of becoming a success story when it began, has become very divisive for the local community.

The original stability of the project was based on a delicate political and economic balance between land owners, local chiefs and dominant families. But with the death of Chief Narua Sasaero, in 1999, this state of equilibrium was comprehensively broken. Narua's family was accused of excluding all the other families from the management of the yacht club, keeping the benefits for themselves exclusively and exploiting a piece of land that had been provided by other families. The breakdown of this community-managed business also coincided with the death of a highly esteemed sea-dweller of the Port Resolution Bay, a tame mature dugong. In the 1990s the dugong had become a major tourist attraction on Tanna. In the eyes of the local villagers, it was never just an ordinary sea mammal. The dugong was thought of as Kassara, the spirit of a local ancestor, belonging to the name-set group of a local chiefly family (Nowar) and even as an avatar of Mwatiktiki, the Tannese name for the well-known trans-Oceanic cultural hero.

The arrival of the dugong in Port Resolution was interpreted as a spiritual symbol, a gift made to the villagers by one of their mighty ancestors in order that people could share the benefits of the expected divlopmen. Fees paid by tourists so that they could swim with the dugong were at first allocated in a strictly communal way and only used for collective projects. With the ill-feeling and quarrels that arose in the wake of Chief Narua's death, this community income was no longer shared. From once being 
a symbol of good fortune, Kassara now represented a new pretext for divisions in the community. When the innocent animal finally died, Fred Nase, a new John Frum prophet (Tabani 2008, 2009), claimed that he was personally responsible for its death, which he had brought about in order to punish the villagers for their greed and for having used a local spirit for the purposes of profit. According to traditional beliefs, spirits have their own means of punishing those for whom the greed for money has overridden the rules and spirit of kastom, but of course no tour operator was ever worried about supernatural risks of that nature. ${ }^{15}$

The initial success of the yacht club in Port Resolution later prompted foreign investors to set up their own Melanesian-style guesthouses, but without any community management or sharing of benefits. Friendly Bungalow in White Sands and Relais de la Baie des Tortues in Turtle Bay, also located on the east coast near the volcano, entered into serious competition at the local level to attract backpackers and other ecofriendly tourists. In Port Resolution this has led to the original investment being divided up. Over a period of 10 years, six different bungalow guesthouses and restaurants have opened, all located in the tiny peninsula of Port Resolution.

This self-interested behaviour has resulted in many personal grievances being aired between the main families of the village. The loss of trust between all of these groups is so strong that still today they have not even reached agreement over the appointment of a new village chief following the death of Narua. Economic inequalities have also arisen between the families who own bungalows and those who rely solely on farming. Furthermore, in other parts of the island, close to Lenakel and especially in the area of the volcano, more than 30 guesthouses have opened their doors-even if a large minority of them host no more than a couple of tourists all year. Nevertheless, the setting up of these bungalows has aroused such envy and greed among nearby villagers that it is now one of the main sources of land conflict. Since then, several hectares in Port Resolution with beach frontages have been sold to foreign investors, awaiting the development of infrastructure to set up hotels as investments.

15 The frustrations and the feelings of powerlessness that have very frequently attended the birth of 'cargo cults' can also arise when the money from tourism is suddenly taken away from rural populations. Such a situation was observed by Eric Silverman (2013) in relation to the communities of the Sepik in a post-tourism context, with the end of the exploitation of cruise ships on the river. 


\section{Tourism, cash earning and social conflicts}

Aside from persistent and extensive land-grabbing, with the beginning of colonisation and especially in the era of the labour trade in the Pacific in the second half of the nineteenth century, Melanesians have experienced some dramatic consequences of wage labour. Powerful tools used to establish the colonial order and maintain its domination over indigenous societies included the exploitation of indigenous labour, the alienation of their land and the introduction of money. Western uses of money-a supreme 'fetish' of fetishised goods and services, of commoditised products according to Karl Marx, or through its domination engendering a special case of alienation in the social and cultural realm, a dehumanisation defined as 'reification' following Georg Lukács-have been analysed in their own way by indigenous societies and frequently criticised as a characteristic component of colonial forms of oppression and domination.

The modern capitalist use of money (labelled 'state monies' by Akin and Robbins (1999); or 'exchange currencies' by Graeber (2012)) in former embedded economies of Melanesia did not succeed in reducing all aspects of social relationships to categories of exchange; traditional monies (respectively named 'local currencies' or 'social currencies' by the authors just quoted) continued to coexist or to combine with the former (Akin and Robbins 1999). In Vanuatu, state monies have more often been accepted and welcomed by Christianised groups (Protestants) than by pagan and later by Catholic and neotraditional groups, with the latter being more prone to reject or to keep separate white men's money, when attempts to control it have failed. However, with its spread into Melanesian societies, the most prized fetish of the White Man increasingly became a destabilising element.

The issue of money also commonly and symptomatically arose in the context of so-called 'cargo cults' or assimilated indigenous movements. On Santo Island, in the 1920s, the Rongoforo cult was categorised as a crisis of insanity, characterised by a special form of delirium on the part of its prophet and his supporters concerning the use of money (Raff 1928). In 1945, also on Santo, the Naked Cult had, as one of its priorities, the rejection of money belong White Man (Guiart 1958). The history of the famous John Frum movement offers numerous discourses about the power, but also the dangers, of money. John Frum's promises of money in plentiful amounts regularly alternated with incredible rushes on Tanna's 
stores by his supporters in order to spend all the money accumulated on the island-when the money was not thrown into the sea. Economic non-cooperation with strangers has also been clearly expressed through the expectation of the Tannese of obtaining their own money: 'By and by money blong me he come, but face blong your fella king, take'em e go back', would threaten John Frum leaders (Guiart 1956: 155). On the new coins awaited by supporters, instead of the king there would be represented a coconut tree (ibid.). ${ }^{16}$ The end of foreign money on the island was to coincide with the departure of foreigners. Prefiguring the slogan painted on walls in Paris in 1968, the Tannese motto in the 1950s was 'never work ... for white men'.

The grey literature of the John Frum Files tells us that, in the 1940s, this rejection of state money was one of the main things of concern to the colonial authorities. ${ }^{17}$ They worried about this problem in particular as it concerned them directly, while other problems more generally related to the power of the missions (Presbyterians and Seventh-day Adventists) over the population. In their materialist analysis, the administrators of the condominium suggested that behind the rise of Johnfrumism on Tanna there was a mismatch between commodity supply and demand. The fall of the price of copra and the global context of World War II had trapped people into a pattern of inactivity. When the stores were empty, attempting to earn money became pointless. In the views of colonial delegates and officers, the commodity market and the trade of manufactured goods should have been reactivated in order to put a stop to this indigenous movement. And indeed, Johnfrumism draws its energy from complete idleness: instead of working and consuming, people spend their days in uncontrolled kava-drinking sessions and erratic dancing flash mobs, outside of any traditional framework. Nevertheless, despite a later increase in the price of copra, nobody went back to work. A rising awareness of exploitation by foreign employers or traders was fuelled by memories of past experiences.

16 In a similar way the Nagriamel movement on Santo, when dissidence in relation to the future independent state was in full swing, established a bank and struck coins, with silver coins representing the emblematic crest of Nagramiel on one side and the portrait of Jimmy Stevens, founder of the movement, on the other. In September 2014, the Turaga nation movement on the island of Pentecost, which militates for the sovereignty of a first pan-Pacific nation, announced, via a campaign of public posters, its intention to adopt and strike its own money.

17 Administrative correspondence, New Hebrides British Service, Southern District 17/11/2 (Western Pacific Archives 1875-1978). 
However, Tannese still have a reputation for being strong workers, if they want or need to work. Their capacity for what they used to call had wok (hard work) has been demonstrated on several occasions: in the cotton fields in Queensland at the end of the nineteenth century, on the docks at Port Vila to unload US army materials or building roads in Efate during World War II, and today in Vila as bus drivers, construction workers or night watchmen. Things are different on Tanna. Such activities as community work, subsistence farming, hunting, fishing or any other productive activity that does not necessitate a financial transactionmekem vatu—are not considered as 'doing work'. Commercial or labour contracts made between Tannese people are always influenced by the social exchange network between nieli (allies or customary partners), even when, at first sight, in a monetised context, this may appear as pure exploitation.

To be one's own master, free to do whatever one likes, is still one of the most prized values in Tanna, and in other islands, regardless of whether it is more and more difficult to sustain that ideal. The opposite of 'hard work' or the 'way of money' is the way of life associated with what Marshall Sahlins (1974) used to describe as the 'domestic mode of production', and could be translated by the Bislama expression stop nomo:

Mi stap nomo ... 'I just live' or 'I just am' ... If you want to eat, you just go to the beach and catch a fish. Otherwise, you go to your garden and grow vegetables. You don't need money, just a little to buy soap or kerosene. But if you want to, you can do without. Mi stap nomo ... This simple, commonly used phrase, adds Miles, speaks volumes about the chasm between a self-subsistence worldview and a developmental one (Miles 1998: 178).

In the past, people in Tanna used to say that there was very little money on the island. But today, with tourism, there are small amounts of money in every neighbourhood and in every house; limited though these amounts certainly are, there is enough for people to think that money can transform their lives, and for them to be greedy to get more. That is why older Tannese regularly remind the younger generation that kastom hemi bitem mani (custom is more powerful than money) or likewise that long kastom evrisamting hemi fri (with custom you don't need money). In the past, ni-Vanuatu never needed large amounts of money. To get money for school fees or other big expenses they had to migrate and find work in Port Vila. Up until now most people would not have considered Tanna to be a place where it is legitimate to make profits. Chief Isak Wan, 
from Sulphur Bay, said to me in his own words: 'Mani hemi gud laef bat mani i mekem man i rabem brata mo sista blong hem' (money can facilitate your life, but it can also lead you to hurt your brother and your sister) (Ipekel village, Tanna, April 2004).

The development of mass tourism in Tanna does not mean the arrival of tourists in vast numbers or a huge increase of money locally. But with around 15,000 tourists a year (to a population of around 30,000 inhabitants), tourism has become a local industry with all of the social and cultural consequences that it involves. Tourism has largely contributed to turning the monetisation of rural communities into a now well-established reality. Until recent times, Tannese people could have been considered to be self-sufficient producers and only marginally as consumers. Today they have become consumers on a much larger scale. Many households are buying an ever-increasing part of their food in shops, while subsistence agriculture and the traditional technological knowledge associated with it are declining (Lebot et al. 2014).

Many young Tannese try to find employment in Port Vila. There they are confronted with an urban economy run by expatriate managers who, in a couple of months or less, can earn what they could expect to earn over a lifetime. ${ }^{18}$ Overseas seasonal working schemes in New Zealand or Australia offer employment conditions that, for many people, are sometimes reminiscent of the old blackbirding scheme, even if working on Taiwanese fishing boats is thought to be much worse. In Lenakel, Tanna's small capital, also called blackmantown since every storekeeper is Tannese while resident expatriates are virtually absent, a considerable amount of capital has already been accumulated, but it is kept hidden under pillows. To display wealth that is not of a traditional kind (except for trucks, which cannot be hidden) is not approved of and can even be dangerous. A route to wealth should be accompanied with secrecy (Rousseau 2015: 27). That is why the local branch of the Vanuatu National Bank is not able to observe any signs of the accumulation of personal wealth in personal accounts (as I was informed by the bank's director in Lenakel, March 2011).

18 Material wealth of 'Whites' is frequently explained in Vanuatu by supernatural means. They are sometimes suspected to individually own a majin blong mekem mani (a machine to make money, not to be confused with automatic cash dispensers like in Port Vila). Once, a group of informators mimed to me how such machine was working: 'Just push on the button and a banknote will appear'. Likewise, the Free Mason Lodge of Mele in Port Vila, locally called Satanik, is commonly considered by ni-Vanuatu as 'a church of white businessmen sacrificing young children to earn a lot of money'. 
Tourism, too, through the monetisation of village communities, has contributed to a growing feeling of social inequality in a rural context. Local indigenous businessmen (storekeepers, tourist operators, truck owners, kava planters, now form a new group of capitalist entrepreneurs, even if they feel ashamed and deny that they belong to a new rural middle class, except when they are in Port Vila or overseas where they can enjoy their newly acquired privileges. In the past, people in Tanna used to say that there were no rich people and no poor people-these words once had no meaning. But today these categories have become real, and some Tannese will add that they feel closer to a poor person from another island than to the rich people from their own island. As one of its many consequences, this has led to a regular increase in the crime rate among the young people of Tanna, not only in Port Vila, but also in their home islands where once criminality was almost unknown. ${ }^{19}$

\section{The commodification of kastom and the business of traditional ceremonies}

The ancestors of the ni-Vanuatu created their own unique, and spectacular, ceremonies. These ritualised events were traditionally used to sustain both the cosmic and social orders, and at the same time to redistribute within the society the benefits of the abundance of food and well-being produced by them. The aesthetic and spiritual achievements of these events were part of people's symbolic investments and magical powers. These ceremonies belong exclusively to them, even if it seems impossible to attribute any specific 'copyright' to the whole ritual process as such. The move to change the spirit of these ceremonies-that is to aim at raising revenue instead of maintaining social relations, celebrated by food and other ritualised exchanges - has mainly come about because of the development of tourism. In Vanuatu, before a couple of decades ago, it never happened that a traditional ceremony was completely recast for exclusively economic purposes.

19 As a result of historically shared views by Christians and John Frum opponent groups against nahak (sorcery), violent reactions to the consequences of changing forms of social stratification did not lead on Tanna to the same increase of sorcery retaliation practices as in urban places or northern provinces of Vanuatu (Rodman 1993; Rio 2010; Taylor 2015; for a comparative insight with PNG about sorcery and modern inequalities see Eves 2000). 
In a former article (Tabani 2010), I highlighted processes of contemporary aestheticisation and commodification of culture in certain important rituals held in Vanuatu. These customs, which have been elevated by different (local as well as foreign) agents to the rank of cultural identity symbols, are the same as those repeatedly shown in tourist brochures that encourage visitors to discover the 'real Vanuatu' via its dramatic and spectacular customs, even though kastom, or rather kastoms in the plural, cannot be reduced simply to the category of the 'performing arts'. The most famous of these regular events in Vanuatu include, notably, the Nagol land dive in the south of Pentecost Island, the Rom dances on Ambrym, the initiatory sand drawings in the northern central islands, the Nakwiari ceremonies and the annual cargoist celebrations of the followers of the John Frum movement on Tanna, every 15 February. Since the 1970s the organisation of 'festivals of traditional arts', held in all the Pacific states, has been added to these; on these occasions, a 'best-of' of national or regional neorituals, in abbreviated and folkoric form, will usually be performed. Through political, commercial and legal processes, the traditional referent of these updated ritualisations has been replaced by a celebration of the kastom theme itself. The valorisation at various levels of Vanuatu's cultural customary heritage appears to be a paradox. Kastom is more and more frequently invoked for political and commercial purposes. Nevertheless, kastom as an ongoing practice, coupled with an idealisation of the ancestral past, is seen by many ni-Vanuatu both as the focus of, and the cure for, the main ills brought by westernisation.

In that article I also pointed to the increasing monetisation of village communities through the global promotion of kastom performances by the media and for the purposes of tourism; at the local level, this monetisation is more and more frequently considered to be a factor of inequality or division. I based parts of my argument on the Nagol ceremonies in South Pentecost, and discussed the differing nature of its national and local political uses, and different aspects of its economic exploitation. ${ }^{20}$

20 The most severe statements about commercial exploitation of Nagol were made by Gratien Tiona, a local ni-Vanuatu journalist:

'The Gaul Land Dive [Nagol] has become a business, an opportunity for earning money ... Over the last few years, the number of dives has increased and the ritual has become a competition ... The members of a council responsible for the Nagol activities are said to have embezzled money brought by foreign visitors whose numbers increase every year ... This practice would have made money for the community of southern Pentecost if the rights had been paid for ... The spirit of collective work 
I had the opportunity to summarise my views at several conferences in Vanuatu and provided a précis of my findings to national and regional newspapers and on radio. My interview for ABC Radio Australia (21 May 2010), followed by The Independent of Vanuatu (22 May 2010), was titled, without my approval, 'Vanuatu's Nagol season denounced as tourist trap'. Among the reactions that followed in Port Vila and Pentecost was that of Nagol ceremonial leaders who were prompted to give their own point of view on the current situation.

In a reply to ABC Radio Australia (28 May 2010), 'High chiefs of Pentecost want more tourists', Luc Fago, who has been in the vanguard of the tourist development of Nagol among the West Coast Christian communities, was not concerned about the dangers resulting from increasing the number of land dives in order to increase their financial benefits. He admitted that the ceremony earned considerable local income. On the occasion of a recent visit to South Pentecost by Serge Vohor, former infrastructure minister, Fago demanded new infrastructure in order that the island could host even more tourists for the event. In his speech for the opening of the Nagol season, he expressed the wish that the government build a wharf so that thousands of tourists from cruise ships would be able to attend the ceremony at each session.

In another response, 'Pentecost Chiefs in Vanuatu move to take control of Nagol ritual' (Vanuatu Daily Post, 9 February 2011), the chiefs of Pentecost Island declared that the tradition had become too commercialised and that they were seeking to regain full control of the ritual. A Vanuatu correspondent, Hilaire Bule, reported that with the ceremony being performed three times a week for tourists the South Pentecost Council of Chiefs, Malbangbang, resolved to take over the entire management of the ritual:

They have to have the control and the good management of the ceremony because they say if they don't have the control, Nagol will lose its traditional value. If they organise three ceremonies per week it means that they have to cut more trees, more vines and it will have a negative impact on the environment of the people of South Pentecost ('Pentecost Chiefs in Vanuatu move to take control of Nagol ritual', Vanuatu Daily Post, 9 February 2011).

has deteriorated and each village has decided to take charge of the Nagol and to organize it as it wishes with a sole aim: to make money' ('Le saut du Gaul à Vaté, c'est l'argent qui compte', Vanuatu Weekly, 30 June 1998). 
Bule also reported that the chiefs of South Pentecost were still to decide how frequently they would allow the ritual to take place, and what kind of commercial limits they wanted to impose on it:

Chiefs from the southern part of the islands have described the decision of South Pentecost Tourism Committee as 'prostitution' of their tradition. They said that three ceremonies per week were putting their environment at risk because people have to cut down more trees and vines to build the tower for each ceremony.

Chief Telkon said it was now time for tour operators to cooperate with chiefs to preserve the traditional values of Nagol which is linked with the harvest of yams. He warned that Malbangbang will not hesitate to take action against the government, National Tourism Office and other stakeholders if they don't cooperate with them. This action could include stopping tourists coming to Pentecost for the land diving (ibid.).

According to Miranda Forsyth, Chief Telkon's criticism of the prostitution of Nagol could 'appear to be an excellent example of "the community" exercising agency over its traditional knowledge' (Forsyth 2012: 15). However, pertinently, she observes that 'a different perspective is given' by an anthropologist who had devoted his $\mathrm{PhD}$ thesis to the traditional land dive ceremonies in Pentecost (see Lipp 2008):

Telkon Watas was the very individual who re-introduced the gol on Pentecost's more easily accessible West coast to attract tourists in the seventies. The massive inflation of gol performances is thus to a large extent his work, or at least an outcome of his initial initiative. He has always benefitted immensely - and often - from it, while the people actually doing the performance, have not - or not much ...

Telkon Watas is a much feared man on Pentecost. He has been accused of mismanagement, betrayal, sorcery, and murder. I would say that all of these accusations are true. As far as I see it, this is yet another move by Telkon Watas, now a man in his seventies, to secure this 'kastom as commodity' for himself and some of his sons. It has nothing to do with an interest in this outstanding and intricate performance itself. What would be much more needed, and would make more sense, is transparency with regards to what happens with the enormous influx of money that the gol tourism generates (Thorolf Lipp, Asaonet discussion list, 19 February 2011; also quoted in Forsyth 2012: 14-15).

Nevertheless, Thorolf Lipp fails to mention that he was himself in conflict with Chief Telkon, who refused to allow him to organise a huge cultural 'collaborative project' in Germany with friends from Pentecost. One of 
the team members died and Chief Telkon was suspected of having killed him by sorcery (Jacob Kapere, personal communication, April 2010). The so-called Ursprung project nevertheless went ahead and was very successful. ${ }^{21}$ Lipp raises the questions: "Who has benefitted from this venture? Who came in touch with it through which communication channels?' (Pigliasco and Lipp 2011: 401), but one might ask, too, to what extent 'collaborative work' also first and foremost benefits the personal career of anthropologists and other professionals in the cultural field-their personal success can thus also lead to kastom's attractiveness for tourism development being reinforced.

The Nagol ceremony, which is practised only by the people of South Pentecost, is one of Vanuatu's most colourful events and attracts thousands of visitors each year during the season. In the 1990s, there was growing interest in the ceremony on the part of commercial film crews, production companies and travel agents. At the same time, the disruption caused to the inhabitants of Pentecost by the inflow of money and by the misappropriation involved in its distribution has increased continually. In 1995, the Vanuatu Government threatened to ban the Nagol. Since then, at the same time as the tradition was being turned into a commercial attraction, its cultural significance was being lost, while the image of the Nagol, the inhabitants of Pentecost and the people of Vanuatu in general were being distorted.

Finally, with the aim of controlling the situation, the VKS decided in January 2006 to place a 'moratorium' on material concerning the Nagol appearing in commercial films and other audiovisual productions organised by foreign firms on Pentecost. Thus, by taking this initiative, the VKS was attempting to convince all the parties involved to join it in:

the elaboration of a coordinated plan for managing the Nagol ceremony in order to preserve its cultural meaning and guarantee the transmission of traditional knowledge to younger generations ... to ensure that the considerable cash revenues generated by the commercial activities related

21 'In Germany, the three exhibitions have so far been visited by approximately 5,000 people and the South Sea Collection in Obergünzburg continues to attract a growing number of visitors. Five radio broadcasts, between three and 30 minutes in length, have been aired, two by the national German cultural program Deutschlandfunk. A half-hour live television broadcast with our [ni-Vanuatu] guests was aired by the Bavarian Broadcasting Association. Seventeen newspaper articles were published, including a full-page article in Munich's largest newspaper, Münchner Merkur, and a half-page article in Germany's biggest tabloid, Bild' (Pigliasco and Lipp 2011: 401-402). 
to the Nagol were properly channelled into sustainable development appropriate to the needs of the communities of this region ('Moratorium - ban - on commercial filming of Nagol, VKS, 1 January 2006).

Attempts to get round the moratorium have already led to one tragedy. The ban did not apply to ni-Vanuatu professionals and, in April 2008, the Australian production company Beyond Productions, acting for the National Geographic Society, is said to have bribed a young cameraman, Hardy Bill Ligo, who worked for the national television channel, to film the ceremonies for them. Excessive risk-taking seems to have destabilised the tower, which collapsed, killing the cameraman instantly ('TV cameraman dies in film shoot', Vanuatu Daily Post, 17 April 2008). The chiefs of South Pentecost claimed that the incident happened as a result of lack of respect for its traditional values. The chiefs said that the ceremony was held outside the appropriate season. In both cases, the main criticism only targets the question of benefits, whether these are increasing or not, and who is authorised to control the performance. Nobody is prepared to address the main issue: are the Nagol divers still ritual performers or are they now merely paid workers, entertainment industry employees? Who is responsible when divers die during a Nagol performance-the spirits of ancestors, kastom chiefs or tour operators and media companies?

The instrumentalisation or the exploitation of these rituals, which are significant religious expressions stemming from an established common cultural heritage, but which nowadays are performed principally to indulge the fantasies of foreign tourists for the profit of outside speculators, is a reality of which most ni-Vanuatu are well aware. The participants in these ceremonies do not see them as false rituals but as rituals that have been diverted from the meaning and purpose they once had. Their commercialisation is on the one hand presented by the state authorities as an aid for local divlopmen and on the other it is experienced by those directly concerned as a growing threat to social cohesion. The most recent episode involving the vicissitudes of the Nagol ceremony occurred in the season of 2015, it shows how the social tensions arising from it are now being expressed in a violent way:

Tourists and visitors watched in disbelief as around 150 people of the Wawan Area on South Pentecost cut down a Nagol tower on the side of Lonoror Airport in the Central part of the island around 11 o'clock Saturday [April 15] in the morning as the performers of the customary or Pentecost jump was about to get underway ... 
Chief [Peter] Watas, who has succeeded chief Telkon Watas who died last year, explained that a resolution from a Malbangbang council of chiefs meeting stipulates that all Wawan custom must only be performed in the South Pentecost area (Vanuatu Daily Post, 17 April 2015).

Chief Watas further explains that in the eight years that the Nagol was staged at Lonoror, the people of South Pentecost have not earned a single vatu from their custom. 'This is because tour agents, who pay money to the Lonoror people, bring tourists to Lonoror Airport by plane. They walk one minute to the Nagol tower and after watching the show they board the plane and head back to Port Vila. Road and sea transports, bungalows and guest houses in Pangi and artefacts vendors from the South Pentecost earn nothing from their custom' ('Lonoror Nagol tower cut down by Wawan people', Vanuatu Daily Post, 17 April 2015).

In Tanna, I regularly asked local participants if it was a good thing that more and more tourists and film crews were coming to watch the performance of the John Frum 15 February ceremonies. Their answers generally fall into two categories. On the one hand, many Tannese think that it is good to use ceremonies to promote the island in order to attract more tourists. But they do not want too many visitors either. And they are scared that they could one day lose control over their own ritual events. On the other hand, villagers who protest against the rise in the number of journalists and film crews, accused of exploiting kastom for personal profit, are, however, often the same as those who hope that there will be a rise in tourist numbers as well. Even if visitors do not pay any direct fee to the villagers, the business generated by such an event outside of the island is widely seen as already having reached the level of the commercial exploitation of the Nagol in Pentecost. A cultural policy is presently endorsed by the Tannese branch (Tafea Kaljoral Senta or TKS) of the Vanuatu Cultural Centre in order to prevent problems arising. Nevertheless, Jacob Kapere, Director of the TKS, provides a realistic statement as to the limits of his agency:

I have regularly attended these John Frum ceremonies for many years. Before, very few tourists and journalists attended this event. Sometimes there were no foreign visitors at all. But today we have the feeling that their number is close to exceeding that of local participants. In order that the situation does not become a problem in Tanna as it already is in Pentecost, the Tafea Kaljoral Senta encourages the communities not to demand money from those who attend the local ceremonial events or who want to film them. We try to assess the needs of local communities in order to provide some material support. The danger lies in dealing with 
money and giving it just to some particular chiefs without then having any control over its collective redistribution. If our policy proves inadequate for maintaining that control, we could ban film crews and journalists from coming, but we could not ban tourists, since we cannot stop the ceremonies themselves (Jacob Kapere, interview, 15 February 2008).

\section{Conclusion}

Knocking down the Nagol tower of a rival group that no longer respects customary copyright and denouncing the unbridled exploitation of the ceremony as 'cultural prostitution' are mostly desperate attempts or admissions of failures. The rural communities of the archipelago no longer have the power to stop the influx of tourists on their lands, as was still possible in the 1970s, nor to prevent them attending cultural events. Massive attendance of tourists to local ceremonies affects their original purpose as inevitably as the growth of tourism remains a major threat for indigenous land. The frequent local conflicts generated by the marketing of elements of traditional cultures could at best bring them to an end, with the risk of destabilising even more the rural communities (comparatively with Fiji see Pigliasco, Chapter 9, this volume). To find solutions to these concerns, tourism projects beneficial to the poor (pro-poor tourism) (Trau 2012) are actually being conceived in Vanuatu. But this type of developmental approach is itself criticised by experts in tourism studies who stress, in relation to these projects, that they are no less capitalist and cannot only be of exclusive benefit to the poor (Harrison 2008).

However, in this context the sensitive subject of cultural prostitution cannot simply be discarded as an expression of a vain even if radical critique. Such sense of humiliation shall be characterised as an allegory of modernity, similar to how it was expressed by Walter Benjamin, when he proposed that 'prostitution can lay claim to being considered "work" the moment work becomes prostitution' (Benjamin 1999: 348). The dual aspect of the fetishism of the merchandise embodied by the figure of the prostitute, both worker and product, is realised in this global context where 'capitalist society creates and enforces a massive and universal commodification, which means prostitution of everything and everybody' (Salzani 2007: 152). Some authors observe that the most virulent criticisms of the marketing of the Nagol have come from anthropology and cultural 
studies (Cheer, Reeves and Laing 2013: 441), an observation that might be extended to ethnic tourism in general. How can we forget, in the Pacific context, the hard-hitting words of someone like Roger Keesing?

Mass tourism and the media have created a new Pacific in which what is left or reconstructed from the ruins of cultural destruction of earlier decades is commoditized and packaged as exoticism for the tourists ... The commoditization of their cultures has left tens of thousands of Pacific Islanders as aliens in their own lands, reduced to tawdry commercialized representations of their ancestors, histories and cultures. Beneath the veneer of fantasy, the Islanders are pauperized in village hinterlands or themselves commoditized as menial employees ... The elites seeking to attract foreign investment and tourist dollars inevitably become complicit in this process of reification and commoditization, the pimps of cultural prostitution (Keesing 1996: 174).

Or those of Christopher Tilley, just as explicit in relation to the Small Nambas of Malekula:

Western influence having successfully destroyed traditional culture is now having the effect, through tourism, of picking over its bones in a show which heartlessly reduces it to an exoticized spectacle for entertainment. The relationship between the dominant and the dominated is simply being reproduced in the post-colonial context in a new virulent form, a prostitution of culture. The exploitation involved substitutes the physical violence and land alienation of colonialism for a more subtle and insidious symbolic violence in which people sell themselves as part of a pan-Pacific human zoo, and thereby their souls (Tilley 1997: 85).

However, anthropologists were not the first to stress the pauperisation and humiliation of rural communities in the Pacific, facilitated by the surge in tourism and the practices that go with it. Early accusations of 'cultural prostitution' were made in 1975, on the occasion of the Festival of Melanesia 2000, the first celebration of a Kanak identity turned into a spectacle (see the tract posted in the streets of Noumea in 1975 by some Kanak revolutionary militants, reproduced in the newspaper Les Calédoniens, no. 4, 1 March 1975: 12-13; see also Graille 2015). Next it was the turn of militant nationalists in Hawai' $i$ to denounce the prostitution of their culture for the benefit of tourism and colonial domination over this state of the Union (Trask 1991). Likewise, Frederick Errington and Deborah Gewertz (1996) commented on insistent complaints in the 1990 s by Chambri peoples in PNG against the 
prostitution of their customs. Next it was the turn of militant nationalists in Hawai' $i$ to denounce the prostitution of their culture for the benefit of tourism and colonial domination over this state of the Union (Trask 1991).

It is scarcely surprising that 10 years later, in Vanuatu, the same causes produce the same effects and bring about the same reactions on the part of the local populations. Just after the archipelago had been struck by the most destructive cyclone in living memory, and the ni-Vanuatu were left with only the clothes on their backs as they lamented the extent of the damage, the national office of tourism rushed to launch an advertising campaign with the slogan 'Vanuatu still smiles'. Stuck in an ideological representation of an idealised precolonial past, exploited for their human, cultural, land, mineral, fishing and environmental resources, the rural communities of Vanuatu now see themselves being offered no other choice by their rulers than that of being 'constrained to smile and "be happy”, because that is part of their symbolic image' (Keesing 1996: 174). Anthropologists could sometimes help to imagine the conditions of a 'sustainable tourism' but it is also their role to warn people that cultural prostitution is not a force for kastom, but rather a sign of 'consuming cultures' (Linnekin 1997) of those for whom kastom is, at least partially, a lived culture.

\section{References}

Akin, David, and Joel Robbins. 1999. 'An introduction to Melanesian currencies: Agency, identity, and social reproduction'. In Money and Modernity: State, and Local Currencies in Melanesia, ed. David Akin and Joel Robbins, pp. 1-40. Pittsburgh: University of Pittsburgh Press.

Akin, David and Joel Robbins (eds). 1999. Money and Modernity: State, and Local Currencies in Melanesia. Pittsburgh: University of Pittsburgh Press.

Babadzan, Alain. 2009. 'L'indigénisation de la modernité: La permanence culturelle selon Marshall Sahlins'. L'Homme 190: 105-28. doi. org/10.4000/lhomme.22118. 
- 2006. 'Culturalism, neo-liberalism and the State: The rise and fall of neo-traditionalist ideologies in the South Pacific'. In Public Policy and Ethnicity: The Politics of Ethnic Boundary Making, ed. Elizabeth Rata and Roger Openshaw, pp. 54-65. New York: Palgrave Macmillan.

—. 1988. 'Kastom and nation-building in the South Pacific'. In Ethnicities and Nations: Processes of Interethnic Relations in Latin America, Southeast Asia, and the Pacific, ed. Remo Guidieri, Francesco Pellizzi and Stanley J. Tambiah, pp. 199-228. Austin: University of Texas Press.

Beasant, John. 1984. The Santo Rebellion: An Imperial Reckoning. Honolulu: University of Hawai'i Press.

Benjamin, Walter. 1999. The Arcades Project, trans. Howard Eiland and Kevin McLaughlin. Cambridge, MA and London: Belknap Press of Harvard University Press.

Bonnemaison, Joël. 1994. The Tree and the Canoe: History and Ethnography of Tanna, trans. Josée Pénot-Demetry. Honolulu: University of Hawai 'i Press.

Brown, Anne M. (ed.). 2007. Security and Development in the Pacific Islands: Social Resilience in Emerging States. London: Lynne Rienner Publishers.

Bryant-Tokalau, Jenny J. 1995. 'The myth exploded: Urban poverty in the Pacific'. Environment and Urbanization 7(2): 109-30. doi. org/10.1177/095624789500700205.

Cheer, Joseph M. 2015. 'After the cyclone: Why relying on tourism isn't in Vanuatu's interests'. The Conversation 15 April. Online: theconversation.com/after-the-cyclone-why-relying-on-tourism-isntin-vanuatus-interests-39874 (accessed 6 September 2016).

Cheer, Joseph M., Keir J. Reeves and Jennifer H. Laing. 2013. 'Tourism and traditional culture: Land diving in Vanuatu'. Annals of Tourism Research 43: 435-55. doi.org/10.1016/j.annals.2013.06.005.

Connell, John. 2007. 'The continuity of custom? Tourist perceptions of authenticity in Yakel Village, Tanna, Vanuatu'. Journal of Tourism and Cultural Change 5(2): 71-86. doi.org/10.2167/jtcc084.0. 
Connell, John and Barbara Rugendyke (eds). 2008. Tourism at the Grassroots: Villagers and Visitors in the Pacific. London and New York: Routledge.

De Burlo, Charles. 1989. 'Land alienation, land tenure, and tourism in Vanuatu, a Melanesian island nation'. GeoJournal 19(3): 317-21. doi.org/10.1007/BF00454578.

Douglas, Ngaire. 1996. They Came for Savages: 100 Years of Tourism in Melanesia. Alstonville: Southern Cross University Press.

Dunn, Marney. 1997. Pandemonium or Paradise. Kath and Bob Paul in the New Hebrides 1946-1980. Bathurst: Crawford House Publishing.

Errington, Frederick and Deborah Gewertz. 1996. 'The individuation of tradition in a Papua New Guinean modernity'. American Anthropologist 98(1): 114-26. doi.org/10.1525/aa.1996.98.1.02a00100.

Errington, Frederick K. and Deborah B. Gewertz. 1999. Emerging Class in Papua New Guinea: The Telling of Difference. Cambridge: Cambridge University Press.

Eves, Richard. 2000. 'Sorcery's the curse: Modernity, envy and the flow of sociality in Melanesian society'. Journal of the Royal Anthropological Institute 6(3): 453-68. doi.org/10.1111/1467-9655.00026.

Forsyth, Miranda. 2012. 'Lifting the lid on "the community": Who has the right to control access to traditional knowledge and expressions of culture?' International Journal of Cultural Property 19: 1-31. doi. org/10.1017/S0940739112000021.

Friedman, Jonathan and James G. Carrier (eds). 1996. Melanesian Modernities. Lund: Lund University Press.

Geismar, Haidy and Ralph Regenvanu. 2011. 'Re-imagining the economy in Vanuatu: An interview with Ralph Regenvanu'. In Made in Oceania: Social Movements, Cultural Heritage and the State in the Pacific, ed. Edvard Hviding and Knut M. Rio, pp. 31-50. Wantage: Sean Kingston Publishing.

Graeber, David. 2012. 'On social currencies and human economies: Some notes on the violence of equivalence'. Social Anthropology 20(4): 411-28. doi.org/10.1111/j.1469-8676.2012.00228.x. 
Graille, Caroline. 2015. 'Des militants aux professionnels de la culture: les représentation de l'identité kanak en Nouvelle-Calédonie (1975-2015)'. PhD thesis. Univeristé Paul-Valery Montpellier-III.

Guiart, Jean. 1958. Espiritu Santo (Nouvelles-Hébrides). Paris: Plon.

- 1956. Un siècle et demi de contacts culturels à Tanna (NouvellesHébrides). Paris: Musée de l'Homme.

Harrison, David. 2008. 'Pro-poor tourism: A critique'. Third World Quarterly 29(5): 851-68. doi.org/10.1080/01436590802105983.

Hassall, Graham. 2007. 'Elite conflict in Vanuatu'. In Security and Development in the Pacific Islands: Social Resilience in Emerging States, ed. Anne M. Brown, pp. 225-47. London: Lynne Rienner Publishers.

Holtz, Andreas. 2010. 'Culture as a political function in the Pacific: Vanuatu and Tonga compared'. Pacific News 34: 24-27.

Howard, Michael C. 1983. 'Vanuatu: The myth of Melanesian socialism'. Labour, Capital and Society 16(2): 176-203.

Hviding, Edvard and Knut M. Rio (eds). 2011. Made in Oceania: Social Movements, Cultural Heritage and the State in the Pacific. Wantage: Sean Kingston Publishing.

Keesing, Roger. 1996. 'Class, culture, custom'. In Melanesian Modernities, ed. Jonathan Friedman and James G. Carrier, pp. 162-78. Lund: Lund University Press.

Lebot, Vincent, Laurent Legendre, Stéphanie Carrière, Laurence Pascal and Marc Tabani. 2014. Végéculture: Ecosystèmes, territoires, ressources vivantes et agricultures 2010. Compte-rendu de fin de projet, programme Agence Nationale de la Recherche (ANR-10-STRA-0011).

Lindstrom, Lamont. 2015. 'Cultural heritage, tradition and tourism on Tanna'. In Pacific Alternatives: Politics of Culture in Oceania, ed. Edvard Hviding and Geoffrey White, pp. 180-99. Oxford: Sean Kingston Publishing.

_ 2011. 'Urbane Tannese: Local perspectives on settlement life in Port Vila'. In Trentenaire de l'indépendance du Vanuatu, ed. Marc Tabani, pp. 255-66. Special issue of the Journal de la Société des Océanistes 133. 
—_. 1993. Cargo Cult. Strange Stories of Desire from Melanesia and Beyond. Honolulu: University of Hawaii i Press.

_- 1982. 'Leftmap kastom: The political history of tradition on Tanna, Vanuatu'. Mankind 13(4): 316-28.

Linnekin, Jocelyn. 1997. 'Consuming cultures: Tourism and the Commoditization of cultural identity in the island Pacific'. In Tourism, Ethnicity, and the State in Asian and Pacific Societies, ed. Robert E. Wood and Michel Picard, pp. 215-250. Honolulu: University of Hawai'i Press.

Lini, Walter Hadye. 1980. Beyond Pandemonium: From the New Hebrides to Vanuatu. Suva: University of the South Pacific.

Lipp, Thorolf. 2008. Gol: Das Turmspringen auf der Insel Pentecost in Vanuatu. Beschreibung und Analyse eines riskanten Spektakel. Berlin: LitVerlag.

Miles, William F.S. 1998. Bridging Mental Boundaries in a Postcolonial Microcosm: Identity and Development in Vanuatu. Honolulu: University of Hawai'i Press.

Morgan, Michael G. 2004. 'Political fragmentation and the policy environment in Vanuatu, 1980-2004'. Pacific Economic Bulletin 19(3): 40-48.

Peck, John G. and Robert J. Gregory. 2005. 'A brief overview of the old New Hebrides'. American Anthropologist 7(4): 269-82.

Pigliasco, Guido Carlo and Thorolf Lipp. 2011. 'The islands have memory: reflections on two collaborative projects in contemporary Oceania'. The Contemporary Pacific 23(2): 371-410. doi.org/10.1353/ cp.2011.0045.

Premdas, Ralph. 1987. 'Melanesian socialism: Vanuatu's quest for selfdefinition'. Journal of Commonwealth and Comparative Politics 25(2): 141-60. doi.org/10.1080/14662048708447514.

Raff, E. 1928. 'Extract from a letter from Rev. E. Raff, Vila, New Hebrides, 10 January 1924'. In Orokaiva Magic, ed. Francis. E. Williams, pp. 100-101. Oxford: Clarendon Press. 
Rata, Elizabeth and Roger Openshaw (eds). 2006. Public Policy and Ethnicity: The Politics of Ethnic Boundary Making. New York: Palgrave Macmillan.

Rio, Knut. 2011. 'Policing the Holy Nation: The state and righteous violence in Vanuatu'. Oceania 81(1): 51-72. doi. org/10.1002/j.1834-4461.2011.tb00093.x.

- 2010. 'Handling sorcery in a state system of law: Magic, violence and kastom in Vanuatu'. Oceania 80(2): 182-97. doi. org/10.1002/j.1834-4461.2010.tb00079.x.

Robbins, Joel. 2005. 'Humiliation and transformation: Marshall Sahlins and the study of cultural change in Melanesia'. In The Making of Global and Local Modernities in Melanesia: Humiliation, Transformation and the Nature of Cultural Change, ed. Joel Robbins and Holly Wardlow, pp. 3-22. Aldershot and Burlington: Ashgate.

Robbins, Joel and Holly Wardlow (eds). 2005. The Making of Global and Local Modernities in Melanesia. Humiliation, Transformation and the Nature of Cultural Change. Aldershot and Burlington: Ashgate.

Robinson, Prue and John Connell. 2008. 'Everything is truthful here. Custom village tourism in Tanna (Vanuatu)'. In Tourism at the Grassroots: Villagers and Visitors in the Pacific, ed. John Connell and Barbara Rugendyke, pp. 77-97. London and New York: Routledge.

Rodman, Margaret C. 1987. Masters of Tradition: Consequences of Customary Land Tenure in Longana, Vanuatu. Vancouver: University of British Columbia Press.

Rodman, William. 1993. 'Sorcery and the silencing of chiefs: "Words on the wind" in postindependence Ambae'. Journal of Anthropological Research 49(3): 217-35. doi.org/10.1086/jar.49.3.3630495.

Rousseau, Benedicta. 2015. 'Finding the diamond: Prosperity, secrecy, and labour in Vanuatu'. Oceania 85(1): 24-37. doi.org/10.1002/ ocea. 5071 .

Sahlins, Marshall. 1999. 'Two or three things that I know about culture'. Journal of the Royal Anthropological Institute 5(3): 399-421. doi. org/10.2307/2661275.

- 1992. 'The economics of develop-man in the Pacific'. Res 21: 12-25. 
——. 1974. Stone Age Economics. London: Tavistock.

Salzani, Carlo. 2007. Constellations of Reading: Walter Benjamin in Figures of Actuality. Oxford and New York: Peter Lang.

Silverman, Eric K. 2013. 'After cannibal tours: Cargoism and marginality in a post-touristic Sepik River society'. The Contemporary Pacific 25(2): 221-57. doi.org/10.1353/cp.2013.0031.

Sope, Barak. 1974. Land and Politics in the New Hebrides. Suva: South Pacific Social Sciences Association.

Tabani, Marc. 2010. 'The carnival of custom: Land dives, millenarian parades and other spectacular ritualizations in Vanuatu'. Oceania 80(3): 329-28. doi.org/10.1002/j.1834-4461.2010.tb00088.x.

—_. 2009. 'Dreams of unity, processes of divisions and indigenous movements: Inter-manipulations as cultural heritage in Tanna (Vanuatu)'. Païdeuma Mitteilungen zur Kulturkunde 55: 27-47.

—_. 2008. Une pirogue pour le Paradis: le culte de John Frum à Tanna (Vanuatu). Paris: Éditions de la Maison des Sciences de l'Homme.

- 2002. Les pouvoirs de la coutume à Vanuatu: traditionalisme et édification nationale. Paris: L'Harmattan.

Taylor, John P. 2015. 'Sorcery and the moral economy of agency: An ethnographic account'. Oceania 80(1): 38-50. doi.org/10.1002/ ocea.5072.

—_. 2010. 'Janus and the siren's call : Kava and modernity in Vanuatu'. Journal of the Royal Anthropological Institute 16(2): 279-96. doi. org/10.1111/j.1467-9655.2010.01625.x.

Tilley, Christopher. 1997. 'Performing culture in the global village'. Critique of Anthropology 17(1): 67-89. doi.org/10.1177/0308275X 9701700105.

Trask, Haunani Kay. 1991. 'Lovely hula hands: Corporate tourism and the prostitution of Hawaiian culture'. Contours 5(1): 8-14. 
TIDES OF INNOVATION IN OCEANIA

Trau, Adam M. 2012. 'Beyond pro-poor tourism: (Re)interpreting tourism-based approaches to poverty alleviation in Vanuatu'. Tourism Planning and Development 9(2): 149-64. doi.org/10.1080/21568316 .2011 .630750 .

Vanuatu Millennium Development Goals Report. 2010. Port Vila: Office of the Prime Minister.

Wood, Robert E. and Michel Picard (eds). 1997. Tourism, Ethnicity, and the State in Asian and Pacific Societies. Honolulu: University of Hawai'i Press. 
This text is taken from Tides of Innovation in Oceania: Value, materiality and place, edited by Elisabetta Gnecchi-Ruscone and Anna Paini, published 2017 by ANU Press, The Australian National University,

Canberra, Australia. 